Bull. Egypt. Soc. Physiol. Sci. 36(1), 13-19

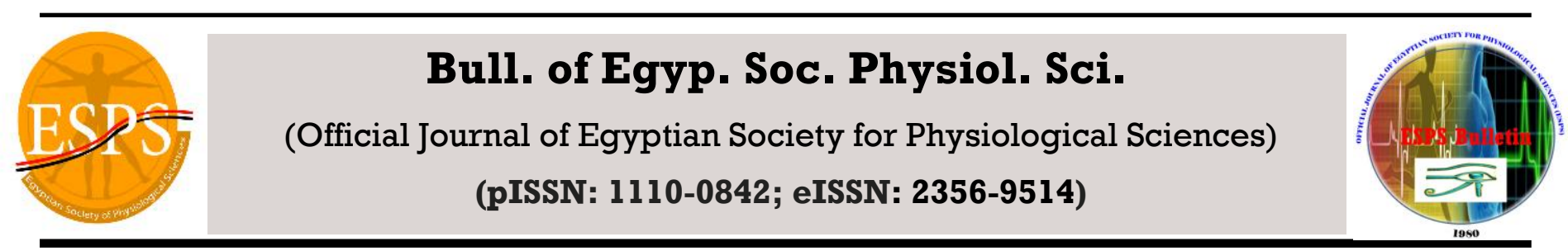

\title{
Effect of Sexual Deprivation Stress on Bone of Albino Female Rats
}

\section{Al Refaey ${ }^{1}$, Ahmad Gadalla ${ }^{1}$, M Zakaria El-Etreby ${ }^{2}$, Hassan Abd Al Hady ${ }^{3}$ Mohammad M. Abo Alfotouh ${ }^{4}$}

\begin{abstract}
${ }^{1}$ Department of Physiology, Faculty of Medicine, Al-Azhar University, Assuit, Egypt, ${ }^{2}$ Department of Physiology, Faculty of Medicine, Al-Azhar University, Cairo, Egypt, ${ }^{3}$ Department of Pathology, Faculty of Medicine, Al-Azhar University, Assuit, Egypt, ${ }^{4}$ Department of Biochemistry, Faculty of Medicine, Al-Azhar University, Assuit, Egypt.
\end{abstract}

Received: 3 Nov 2015

Accepted: 5 Jan 2016

Available online: 29 March

2016

\section{Keywords}

- Stress

- Sexual deprivation

- Bone remodeling

\begin{abstract}
Sexual deprivation stress leads to mental or sexual disorder that can occur after exposure to relative long period of not having sexual relation. Objective: The present work was undertaken to evaluate the possible effects of sexual deprivation on bone remodeling. Materials and Methods: Forty mature adult rats (twenty males and twenty females), of local strains were chosen to be the model of this work , 120-140 gm and aged two months old. They were kept on special formulated diet and tap water was freely allowed. The rats were housed in a wire mesh cage with plastic floor. Each cage was $25 \times 25 \times 30 \mathrm{~cm}$. All rats were housed in a laboratory room subjected to normal light dark cycle, All rats were kept for 21 days in the laboratory room at comfortable room temperature for adaption before any experimental interference and to allow a copulation between male and female before deprivation. The whole length of experiment was two months i.e. twelve estrous cycle. The rats were randomly divided into two equal groups, control group, experimental group. Experimental group were exposed to sexual deprivation for 40 days. Vaginal smear examination, was performed approximately at the same time each day over the course of study for detection of acopulatory plug or by observation of spermatozoa in the vaginal smear.Also determination of serum estrogen, progesterone, calcium, phosphorus, parathormone and alkaline phosphatase enzyme in all female rats was done at the end of experiment. Also, morphology of bone and ovary in all female rats were evaluated at the end of experiment. Results: Experimental group showed significant decreased in serum calcium, estrogen and progesterone hormones compared to control group and significant increased in serum parathormone hormone, blood phosphorous level and alkaline phosphatase enzyme compared to control group. As regard histological picture of bone, our results showed that abnormal structure of bone that consisted of discrete cortex and epiphyseal plate (cartilage). Conclusion: The female rats alleged to sexual deprivation may suffer from alteration in the metabolism of bones which may lead to pathological disease called osteoporosis.
\end{abstract}

Corresponding author: Ahmed Gadalla, Department of Physiology, Faculty of Medicine, Al-Azhar University, Assuit, Egypt. Email: ahmedgadeallah@gmail.com - phone: 01006563412 


\section{INTRODUCTION}

Stress is psycho physiological response and adaptation by our bodies to the real or perceived changes and challenges in our lives ${ }^{[1]}$. Stress is also defined as a state of threatened homeostasis or disharmony and is counteracted by a complex repertoire of physiologic and behavioral response that re-establishes homeostasis [2]. Sexual deprivation is one of the stressful factors which could adversely affect health. It impairs neurobehavioral and reproductive functions [3]. Bone remodeling is a lifelong process where in old bone is removed from the skeleton and new bone is added. Remodeling involves continuous removal of discrete packets of old bone, replacement of these packets with newly synthesized proteinaceous matrix, and subsequent mineralization of the matrix to form new bone ${ }^{[4]}$. The present work was undertaken to evaluate the possible effects of sexual deprivation as a type of stress on bone remodeling.

\section{MATERIALS AND METHODS}

Forty mature adult rats (twenty males and twenty females), of local strains were chosen to be the model of this work , 120-140 gm and aged two months old . They were kept on special formulated diet and tap water was freely allowed. The rats were housed in a wire mesh cage with plastic floor. Each cage was $25 \times 25 \times 30 \mathrm{~cm}$. All rats were housed in a laboratory room subjected to normal light dark cycle, All rats were kept for 21 days in the laboratory room at comfortable room temperature for adaption before any experimental interference and to allow contact between male and female before deprivation. The whole length of experiment was two months i.e. twelve estrous cycle.
Rats were randomly divided into two groups:

A- Control group: Twenty mature adult rats (ten males and ten females). Each cage contained one adult male with one adult female without barrier.

B- Experiment group: Twenty adult rats (ten males and ten females). The rats of this group were kept in ten metal cages which were divided into two compartments by a fixed wire mesh. In each cage, a male was put in one compartment and a female in the other compartment to allow visual and olfactory arousal of the female by the urine of the males .The time of sexual deprivation was 40 days for experimental group. All female rats were subjected to:

I- Vaginal smear examination, was performed approximately at the same time each day over the course of study for detection of acopulatory plug or by observation of spermatozoa in the vaginal smear . ${ }^{[5]} \cdot{ }^{[6]}$.

II - Blood sampling: At the end of the experiment, blood was withdrawn by retro-orbital puncture from all female rats. Determination of estrogen, progesterone, calcium, phosphorus, parathormone, and alkaline phosphatase enzyme in serum.

III-Histopathological study:At the end of experiment both ovaries were dissected and one hind limb was excised from all female rats for histopathological examination .

IV-Statistical analysis: The quantitative data were presented in the form of mean \pm standard error (S.E). One way analysis of variance (ANOVA) followed by Tukey-Kramer as a post-hoc test was done to compare between the studied groups ${ }^{[7]}$. All statistical analysis were performed using analysis of variance technique by means of computer software package. 


\section{RESULTS}

Mating (copulation) in all rats in first 3 weeks is confirmed by the presence of acopulatory plug or by observation of spermatozoa in the vaginal smear. Also mating in control groups is confirmed by the presence of acopulatory plug or by observation of spermatozoa in the vaginal smear all the course of study. Experimental group showed significant decreased in serum calcium, estrogen and progesterone hormones compared to control group and significant increased in serum parathormone hormone and alkaline phosphates enzyme compared to control group. Experimental group showed also significant increase in blood phosphorous level compared to control group. (Table 1 and 2 ).

\section{Histopathological examination:}

Bone sections of experimental group showed abnormal structure of bone i.e. discrete cortex and epiphyseal plate (cartilage). The trabecular plates were thin, irregular and widely spaced (multiple pores), trabeculae was short, lined by osteoblast and adjacent bone marrow contained two large gaint oseoclastic cells (Fig.1). Ovary sections showed abnormal ovarian structure i.e. few primary graffian follicle which lined by single layer of granulosa cells (Fig.2).

Table (1): Effect of sexual deprivation on serum level of calcium, phosphorous and parathormone (Mean \pm standard error) in control and experimental group.

\begin{tabular}{|l|c|c|c|}
\hline Parameters & $\begin{array}{c}\text { Calcium } \\
\mathrm{mg} / \mathrm{dl}\end{array}$ & $\begin{array}{c}\text { phosphorus } \\
\mathrm{mg} / \mathrm{dl}\end{array}$ & $\begin{array}{c}\text { Parathormone } \\
\mathrm{pg} / \mathrm{ml}\end{array}$ \\
\hline Groups & $\begin{array}{c} \pm 0.32 \\
9.23\end{array}$ & \pm 0.104 .02 & \pm 1.0341 .44 \\
\hline Control & $\begin{array}{c}6.42 \pm \\
0.33^{\mathrm{a}}\end{array}$ & $7.15 \pm 0.12^{\mathrm{a}}$ & $54.36 \pm 0.55^{\mathrm{a}}$ \\
\hline
\end{tabular}

-Data are expressed as means \pm SEM of ten rats per groups.

-Multiple comparisons were accomplished using one way ANOVA followed by Tukey-

Kramer as a post-hoc test.

- a Significantly different from control group at $\mathrm{P} \leq 0.05$.

Table (2): Effect of sexual deprivation on serum level of alkaline phosphatase, estrogen and progesterone (Mean \pm standard error) in control and experimental group.

\begin{tabular}{|l|c|c|c|}
\hline Parameters & $\begin{array}{c}\text { Alkaline } \\
\text { phosphates } \\
\mathrm{u} / \mathrm{l}\end{array}$ & $\begin{array}{c}\text { Estrogen } \\
\mathrm{ng} / \mathrm{ml}\end{array}$ & $\begin{array}{c}\text { Progesterone } \\
\mathrm{ng} / \mathrm{ml}\end{array}$ \\
\hline Groups & $23.30 \pm 0.68$ & \pm 0.3013 .98 & \pm 0.9947 .77 \\
\hline Control & $31.30 \pm 0.88^{\mathrm{a}}$ & $10.01 \pm 0.48^{\mathrm{a}}$ & $36.55 \pm 1.00^{\mathrm{a}}$ \\
\hline Experimental &
\end{tabular}

-Data are expressed as means \pm SEM of ten rats per groups.

-Multiple comparisons were accomplished using one way ANOVA followed by Tukey-Kramer as a post-hoc test.

- a Significantly different from control group at $\mathrm{P} \leq 0.05$. 


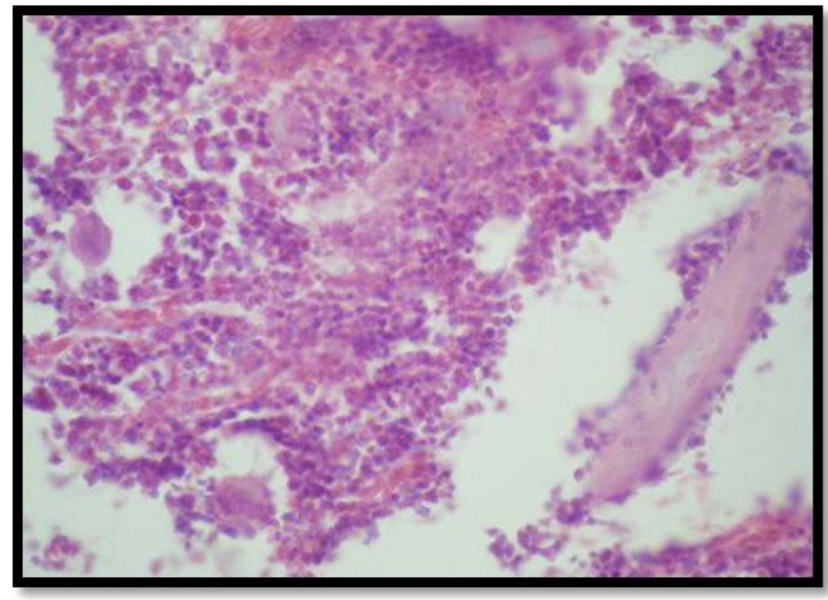

Fig(1): Bone from experimental group showing one trabeculae . It short, lined by osteoblast and adjacent bone marrow contains two large gaint oseoclastic cells (Hx \& E X 400 ).

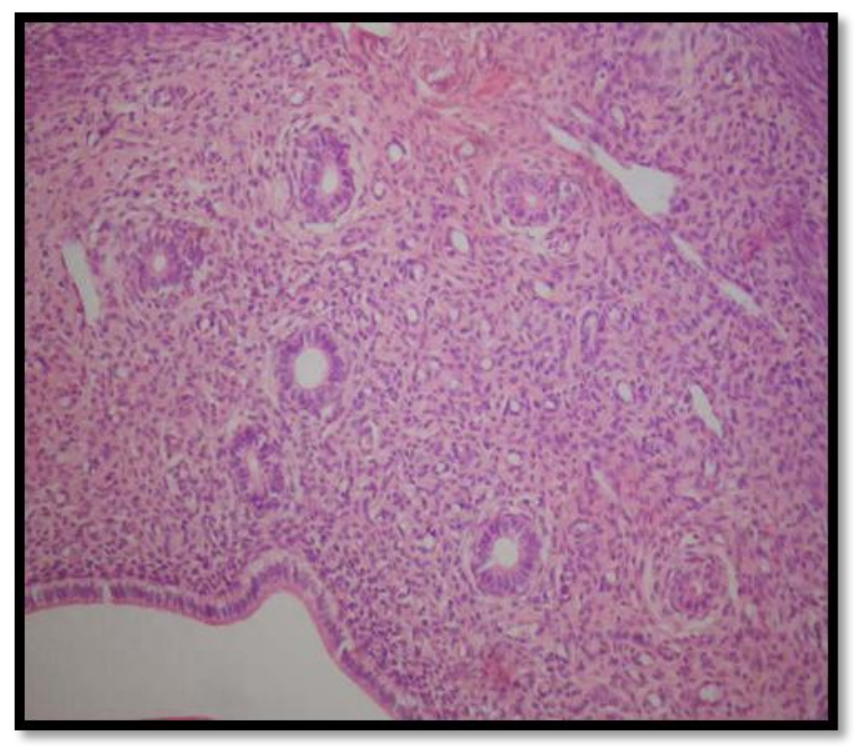

Fig(2): Section from ovary of experimental group showing few primary graffian follicules which lined by single layer of granulosa cells(Hx\&EX200).

\section{DISCUSSION}

Stress in general, whatever its nature, may alter the homeostasis of the organism and may lead to bad back draws that may prone to considerable pathological conditions. Hormonal imbalance is a quite common among people, especially during present time, owing to many factors like stress, late marriages, early sexual copulation, lifestyle changes, environmental changes etc. When the hormone levels fluctuate, it cause a lot of mental and physical anxiety and disturbances in body functions leading to mood swings, changes in sexual desire and act ${ }^{[8]}$. The reproductive system is one of the essential systems that aids to survive of any species. Stress response acts as an alarm system that helps the organisms to cope with any actual or potential threat of survival or homeostasis ${ }^{[9]}$. The reproductive system in rats are good model to study those in human. Although there is no menstruation at the end of each cycle in rats, yet structural and functional changes in the reproductive organs are closely related to those happening in humans ${ }^{[10]}$.

In the present work ,the sexual deprivation lead to significant decreased in level of estrogen and progesterone hormone. Results of the present study were in agreement with ${ }^{[11]}$ reported that, heat stress induced ovarian depression, reduced plasma luteinizing hormone and ovarian steroids, estrogen and progesterone. Also, ${ }^{[12]}$ reported that, cold stress exposure in female mice terminated egg laying, induced ovarian regression, reduced plasma luteinizing hormone and ovarian steroids include estrogen and progesterone. Also, [13] reported that, estrogen production by granulose cells and the plasma concentration of estrogen in heat stressed goat was significantly lower within 36-54 hours than non stressed goats, while the concentration of follicle stimulating hormone (FSH) and progesterone showed no changes between stressed and non stressed goats.

On the other hand, results of the present study were incompatible with ${ }^{[14]}$ stated that, chronic exposure to stress caused an increase in the estrogen level in female rats and claimed that estrogen has a major role in resisting stress. Also, ${ }^{[15]}$ who stated that the concentration of progesterone in the follicular fluid was higher in cows that had been previously stressed than in non stressed cows . 
In the present work, the sexual deprivation leads to significant decreased in level of serum calcium . It is known that estrogen aiding in intestinal absorption of calcium. Having low estrogen levels negatively lead to impaired calcium absorption from the intestine and leads to hypocalamia . $\left({ }^{16}\right)$ This results also explained by that high phosphate leads to reduction of formation of the active form of vitamin D (calcitriol) in the kidneys and this reduces blood levels of calcium ,also decreased calcium level may be due to hyperphosphatemia because hyperphosphatemia can lead to $\mathrm{Ca}$ precipitation into soft tissues,.$\left({ }^{17}\right)$ Results of the present study were in agreement with ${ }^{[14]}$ stated rats exposed to isolation stress leads to hypocalcaemia due to decrease in estrogen secretion which in turn increased renal excretion of calcium and decreased intestinal calcium absorption.

An interesting finding of the current study is that the serum phosphorus level showed significant increase in experimental group when compared to control group. This result was compatible with ${ }^{[18]}$ who stated that rabbits exposed to chronic isolation stress leads to hyperphosphatemia and hypocalcaemia .

In the present work, results revealed that, there was significant increased in serum alkaline phosphatase enzyme. This result can be explained by that, defect in bone mineralization due to decrease calcium level which in turn decrease calcium deposition in bone lead to defect in osteoblast activity which liberate alkaline phosphatase enzyme. This result is compatible with [19] stated that, alkaline phosphatase is increased in a variety of tissues in isolated mice for 2 months .

In the present work, results revealed that, there was significant increased in serum parathyroid hormone (PTH) level. This result may be explained by that, decreased in serum calcium level lead to stimulation of parathyroid gland to secrete parathormone hormone throgh negative feedback mechanism, under stress. This explanation were in agreement with [20] stated that, parathyroid hormone (PTH) is increased in cold stressed rats. The secretion of PTH is mainly regulated by the extracellular ionized calcium level through a negative feedback mechanism . thus, a high ionized calcium level reduce the PTH secretion, and conversely, a fall in ionized calcium increase the PTH secretion.

As regard histological examination in experimental group compared to normal control showed discrete cortex and epiphyseal plate (cartilage). The trabecular plates were thin, irregular and widely spaced (multiple pores), trabeculae was short, lined by osteoblast and adjacent bone marrow contained two large gaint oseoclastic cells. This result is agree with ${ }^{[21]}$ stated that isolation stress in rabitts showed reduction in the number and thickness of trabeculae, besides loss of connectivity between trabeculae, resulting in decreased bone strength.

Also ovary sections in experimental group compared to normal control showed abnormal ovarian structure i.e. few primary graffian follicle which lined by single layer of granulosa cells. From all results we may indicated that the female rats alleged to sexual deprivation may suffered from alteration in the metabolism of their bones, leading to osteoporosis which defined as diffuse skeletal disease characterized histopathologically by an absolute decrease in bone mineralization.

\section{Conclusion:}

Despite of this result it is difficult to confirm that, the female rats alleged to sexual deprivation suffered from osteoporosis. So, the relation between bone and stress need to furthermore researches to applying new 


\section{REFERENCES}

1. Aldwin, C. M. (2007): Stress, coping, and development: An integrative_perspective, Guilford Press. 2(3), 154-160.

2. Seaward, B. L. (2013): Managing stress, Jones \& Bartlett Publishers. 5(2), 14-18.

3. Basson, R., Rees, P., Wang, R., Montejo, A. L. and Incrocci, L. (2010). Sexual function in chronic illness. The journal of sexual medicine, 7(1pt2), 374-388.

4. Witten, P. Eckhard, Anne Hansen, and Brian K. Hall. (2001): Features of mono-and multinucleated bone resorbing cells of the zebrafish Danio rerio and their contribution to skeletal development, remodeling, and growth. Journal of Morphology 250.3: 197-207.

5. Ronal D Hood . (2015) : Developmental and Reproductive Toxicology: A Practical Approach, Third Edition ; 195.

6. Yener T, Turkkani Tunc A, Aslan $\underline{\mathrm{H}}, \underline{\text { Aytan }} \mathrm{H}$ and Cantug Caliskan $\mathrm{A}$. (2007) : Determination of oestrous cycle of the rats by direct examination Feb;36(1):75-7.

7. Quirk, T. J., Quirk, M. and Horton, H. (2013): One-Way Analysis of Variance (ANOVA). In Excel 2007 for Biological and Life Sciences Statistics (pp. 159-174).

8. Clarke, B. (2008). Normal bone anatomy and physiology. Clinical journal of the American Society of Nephrology 3(Supplement 3): S131-S139.

9. Moberg, G. P. (2000): Biological response to stress: implications for animal welfare. The biology of animal stress: basic principles and implications for animal welfare, 1-21.

10. Bandura, A. (2006): Toward a psychology of human agency. Perspectives on psychological science, 1(2), 164-180.
11. De Rensis, F. and Scaramuzzi, R. J. (2003): Heat stress and seasonal effects on reproduction in the dairy cow-a review. Theriogenology, 60(6), 1139-1151.

12. Goltzman D (2011) : Clinical manifestation of hypocalcaemia in adults , 5, 55-57.

13. Angelier, F., Wingfield, J. C., Tartu, S. and Chastel, O. (2015): Does prolactin mediate parental and life-history decisions in response to environmental conditions in birds? A review. Hormones and behavior.125(4), 721-730.

14. Ozawa, M., Tabayashi, D., Latief, T. A., Shimizu, T., Oshima, I. and Kanai, Y. (2005): Alterations in follicular dynamics and steroidogenic abilities induced by heat stress during follicular recruitment in goats. Reproduction, 129(5), 621-630.

15. Bao, A. M., Meynen, G., and Swaab, D. F. (2008): The stress system in depression and neurodegeneration: focus on the human hypothalamus. Brain research reviews, 57(2), 531-553.

16. Wolfenson, D., Roth, Z. and Meidan, R. (2000): Impaired reproduction in heatstressed cattle: basic and applied aspects. Animal reproduction science, 60, 535-547.

17. Kovacs, C. S. (2005): Calcium and bone metabolism during pregnancy and lactation. Journal of mammary gland biology and neoplasia, 10(2), 105-118.

18. Holick, M. F., Binkley, N. C., BischoffFerrari, H. A., Gordon, C. M., Hanley, D. A., Heaney, R. P. and Weaver, C. M. (2011). Evaluation, treatment, and prevention of vitamin D deficiency: an Endocrine Society clinical practice guideline. The Journal of Clinical Endocrinology \& Metabolism, 96(7), 19111930.

19. Golub, E. E. and Boesze-Battaglia, K. (2007): The role of alkaline phosphatase in mineralization. Current Opinion in Orthopaedics, 18(5), 444-448. 
20. Garfia, B., Cañadillas, S., Canalejo, A., Luque, F., Siendones, E., Quesada, M. and Rodríguez, M. (2002). Regulation of parathyroid vitamin D receptor expression by extracellular calcium. Journal of the American Society of Nephrology, 13(12), 2945-2952.

21. Rossini, M., Zanotti, R., Viapiana, O., Tripi, G., Orsolini, G., Idolazzi, L. and Gatti, D. (2014): Bone involvement and osteoporosis in mastocytosis. Immunology and allergy clinics of North America, 34(2), 383-396. 


$$
\begin{aligned}
& \text { تأثير ضغط الحرمان الجنسى على العظم فى إناث الفئران البيضاء }
\end{aligned}
$$

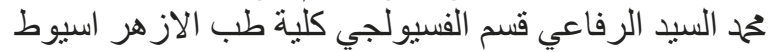

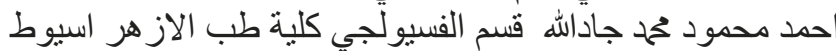

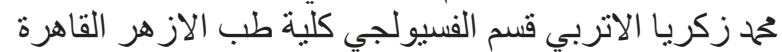

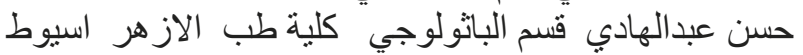

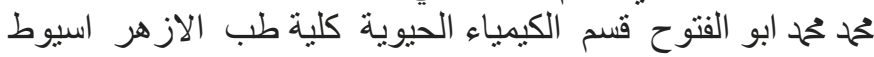

* مقدمة : لقد أصبحت الضغَط النفسية من ألكثر المشاكل التى تواجة الانسان ومن بين هذه الضغوط الحرمان الجنسى الذى أصبح

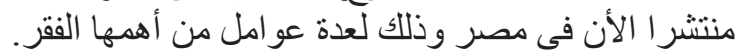
* الهُف من البحث : تهدف هذه الرساله الى دراسة تأثير الحرمان الجنسى كأحد الأحتياجات ال سيكوفسيولوجية على التركيب

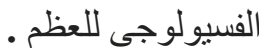
* طريقة البحث: وقد أجرى الاختبار على اربعين فأر ا بالغا (عشرون ذكر او عشرون انتى) من الفئران البيضاء من سلالة مصرية.

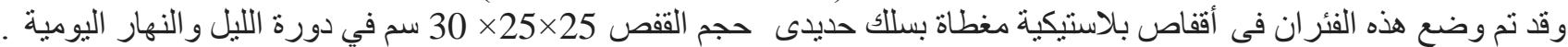

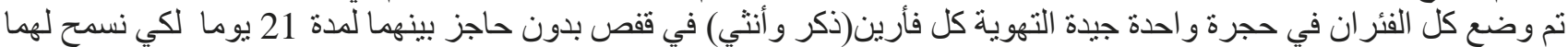

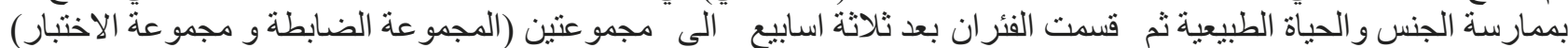

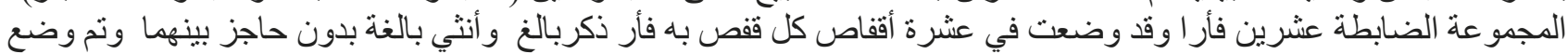

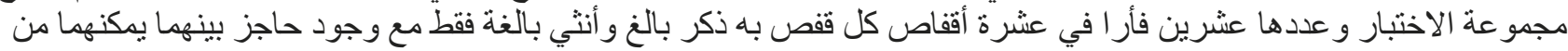

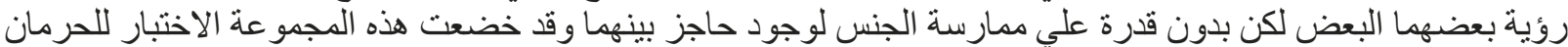

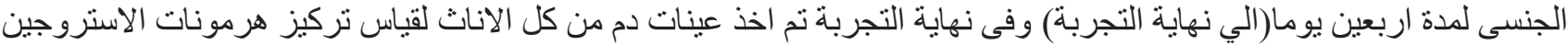

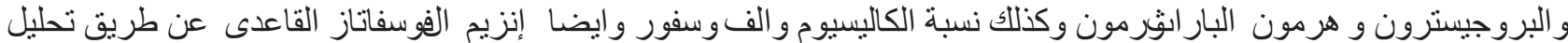

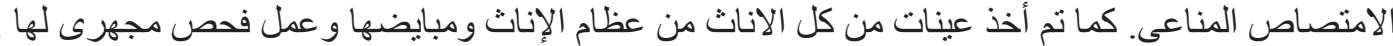

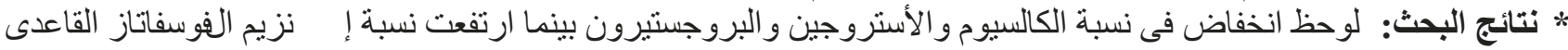

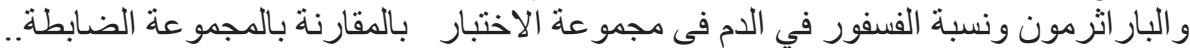

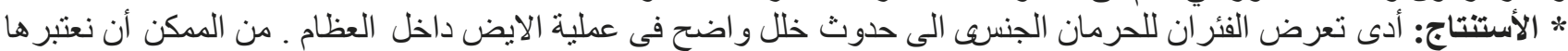

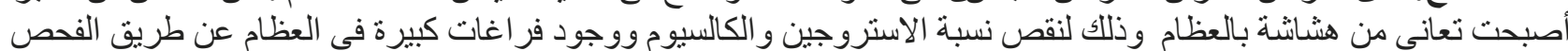

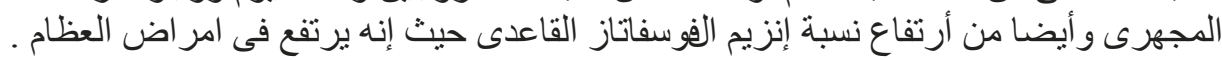

